\title{
TINJAUAN SOSIOLOGI SASTRA PADA NOVEL TARIAN BUMI KARYA OKA RUSMINI
}

\author{
Siti Chodijah Juniati dan Rerin Maulinda \\ Program Studi Sastra Indonesia, Universitas Pamulang \\ dosen00445@unpam.ac.id
}

\begin{abstract}
Abstrak
Penelitian ini bertujuan untuk mengetahui permasalahan sosial yang dilihat dari gambaran gejala sosial, hubungan sosial, dan nilai-nilai sosial pada latar dan tokoh dalam karya sastra yaitu novel. Permasalahan sosial tersebut menyangkut budaya dan adat istiadat Bali sehingga diperlukan teori-teori yang menyangkut dengan permasalahan dalam novel. Dengan demikian penelitian ini menggunakan teori strukturalisme dan pendekatan sosiologi sebagai data analisis. Sedangkan bahan dasar analisis adalah novel Tarian Bumi karya Oka Rusmini yang secara gamblang menggambarkan permasalahan sosial yaitu adanya perbedaan dalam kodrat hidup manusia yang telah diterima sebagai masyarakat adat yaitu status sosial sehingga kebahagiaan pun yang diterima juga berbeda dan butuh perjuangan yang keras untuk mendapatkan kebahagiaan tersebut. Dalam penelitian ini didapati bahwa analisis secara sosiologi sastra dapat mengungkapkan permasalahan sosial, yaitu dapat mengungkapkan gejala-gejala sosial, hubungan sosial, dan nilai-nilai sosial dalam novel secara jelas. Dengan demikian diharapkan dapat memberi wawasan yang lebih luas kepada penulis maupun pembaca mengenai masalah sosial dalam karya sastra.
\end{abstract}

\section{Pendahuluan}

Karya sastra pada dasarnya merupakan hasil pemikiran sebuah masyarakat, dalam hal ini masyarakat diwakili oleh seorang pengarang karena sastrawan sendiri adalah anggota masyarakat. Damono menyebutkan dalam Sosiologi Sastra Sebuah Pengantar Ringkas bahwa sastrawan adalah anggota masyarakat, ia terikat oleh status sosial tertentu (1978: 1). Dari konteks tersebut dapat diartikan bahwa karya sastra merupakan perwujudan dari pemikiran masyarakat terhadap keadaan sosial mereka sehingga menjadikan karya sastra sebagai cerminan sebuah masyarakat tertentu.

Dalam perkembangan kesusastraan Indonesia beberapa karya sastra menggambarkan kehidupan masyarakat. Seperti awal munculnya Balai Pustaka yaitu pada Siti Nurbaya (1922) karya Marah Rusli yang menggambarkan kehidupan masyarakat Sumatra Barat hingga sekarang karya sastra selalu terikat dengan unsur sosialnya. Panuju dalam Ilmu Budaya Dasar dan Kebudayaan 
menyebutkan bahwa sastra semakin dekat dengan persoalan hidup manusia kebanyakan (1994: 78). Selain itu, Ratna dalam Teori, Metode, dan Teknik Penelitian Sastra juga menyebutkan bahwa karya sastra khususnya novel dianggap paling dominan dalam menampilkan unsur-unsur sosial (2009: 335).

Berdasarkan uraian di atas penulis menyimpulkan bahwa karya sastra tidak lepas dari masyarakat yang membentuknya karena dari kehidupan itulah pengarang dapat menampilkan karya yang bisa mewakili keadaan sosial tertentu.

Menghubungkan antara novel dengan masyarakat, maka yang paling berperan untuk mengetahui nilai sosial adalah pendekatan sosiologi. Menurut Damono mengutip Daiches bahwa kritik sosiologis paling bermanfaat apabila diterapkan pada prosa (1978: 12). Pendekatan sosiologi ini beranggapan bahwa prosa merupakan karya sastra yang sesuai untuk ditelaah karena lebih banyak mengisi unsur-unsur sosial dibanding dengan karya sastra lainnya seperti puisi dan drama. Dalam hal ini, dapat penulis simpulkan bahwa prosa adalah karya naratif yang secara jelas dan kompleks menggambarkan nilai-nilai sosial sehingga pendekatan tersebut mampu mengemukakan masalah sosial dan gejala-gejala sosial dalam prosa tertentu.

Uraian di atas dapat diartikan bahwa karya sastra dapat dihubungkan dengan pendekatan sosiologi karena dengan pendekatan tersebut akan membawa pemahaman tentang kehidupan masyarakat. Ratna menyebutkan bahwa pendekatan sosiologi juga memiliki implikasi metodologis berupa pemahaman mendasar mengenai kehidupan manusia dalam masyarakat (2009: 61). Dengan hal itu, Sosiologi sastra sebagai multidisiplin mampu mengungkapkan gejala-gejala sosial seperti hubungan masyarakat terhadap suatu budaya daerah tertentu di dalam sebuah karya sastra.

Dalam menggambarkan kehidupan masyarakat karya sastra menampilkan kebudayaan karena budaya merupakan bagian dari masyarakat. Pradopo mengutip Teeuw (1980: 11) dalam Beberapa Teori Sastra, Metode Kritik, Dan Penerapannya menyebutkan bahwa tidak ada karya sastra lahir dalam kekosongan budaya (2005: 57). Dari konteks tersebut diungkapkan juga oleh Ratna sebagai berikut: 
Sebuah novel, cerita pendek, bahkan satu bait puisi selalu tampil sebagai subordinasi genre, periode, struktur sosial dan kebudayaan yang lebih luas, demikian seterusnya yang pada gilirannya tidak memungkinkan untuk melepaskan karya tersebut dari kerangka sosial-kultur yang menghasilkannya (2009: 94).

Berdasarkan kedua konteks di atas dapat penulis kemukakan bahwa budaya merupakan bagian dalam terbentuknya sebuah karya sastra. Hal ini menunjukkan karya sastra merupakan hasil perwujudan dari pemahaman masyarakat terhadap budaya.

Munculnya Balai Pustaka pada 1920-an melahirkan pemikiran modern terhadap sastrawan. Dalam karya mereka sudah memasukan unsur internasional yang dipengaruhi oleh kesusastraan Barat (Belanda) seperti pertentangan adat dan emansipasi wanita. Pradopo memberikan contoh pada Siti Nurbaya, Layar Terkembang, dan Belenggu (2005: 61). Dalam ketiga novel tersebut sama-sama menggambarkan tokoh wanita yang berjuang untuk menyamaratakan posisinya dengan kaum laki-laki dalam masyarakat. Pengarang dari novel-novel tersebut benar-benar mengetahui dan menghayati persoalan-persoalan yang dihadapi tokoh-tokohnya dalam menghadapi tata kemasyarakatan yang ada pada saat itu.

Akan tetapi, pada akhir Balai Pustaka dan Pujangga Baru sampai pada 1970-an mulai tampak pula unsur kedaerahan yang mulai masuk ke dalam sastra nasional. Pradopo menyebutkan bahwa unsur kedaerahan itu berupa latar sosialbudaya daerah (2005: 61). Dalam bentuk prosa penulis memberi contoh pada karya Umar Kayam dalam Sri Sumarah dan Bawuk (1975) yaitu menggambarkan latar sosial-budaya Jawa, meskipun tidak disebutkan secara langsung latar tempat dalam novel, namun pengarang mampu menampilkan tokoh-tokoh yang memberikan gambaran-gambaran yang cukup jelas tentang budaya Jawa.

Karya sastra dengan unsur kedaerahan juga tampak pada angkatan 1990 sampai dengan 2000-an, meskipun jarang ditemui namun masih terdapat sastrawan yang menggunakan unsur daerah sebagai inspiratif karyanya, seperti karya Oka Rusmini dalam Tarian Bumi (2000), Sagra (2001), dan Kenanga 
(2003). Karya-karyanya tersebut banyak mengangkat persoalan adat-istiadat dan traidisi Bali yang kolot dan sangat merugikan perempuan sehingga dapat dikatakan karya Oka Rusmini merupakan karya yang kontroversial dan fenomenal.

Oka Rusmini seringkali mengangkat persoalan adat-istiadat Bali dalam karyanya karena ia dibesarkan di kultur Bali. Panuju mengutip Umar Junus pada Contant Analysis menyimpulkan bahwa adanya kemungkinan hubungan antara cerita sebuah novel dengan suatu dunia pribadi (1994: 77). Selain itu menurut Escarpit dalam Sosiologi Sastra menyebutkan bahwa semua fakta menyiratkan adanya penulis (2008: 23).

Berdasarkan uraian di atas penulis menyimpulkan bahwa tidak menutup kemungkinan Oka Rusmini menggunakan kehidupan pribadinya sebagai inspirasi dalam karyanya karena gambaran yang ditampilkan sangat rinci mempersoalkan masalah sosial, kebudayaan, dan adat-istiadat Bali.

Tarian Bumi sangat gamblang mempersoalkan status sosial antara kaum Brahmana dan kaum Sudra sehingga konflik dalam novel dengan kehidupan sosial pengarang sangat berpengaruh dalam penciptaannya karya sastra. Subagio dalam Sekilas Soal Sastra dan Budaya mengungkapkan bahwa para pengarang membela diri dengan kegiatan sastra untuk mempertahankan nilai-nilai kemanusiaan dan keagamaan yang menyatukan kehidupan masyarakat (1999: 234). Dalam hal ini menunjukkan bahwa pengarang dapat mengekspresikan perasaan dan pemikirannya dalam karya sastra. Dengan itu menurut penulis Tarian Bumi dapat menampilkan gambaran gejala-gejala sosial terutama nilai kemanusiaan yang diperkaya oleh latar sosial-budayanya secara rinci dan lebih kompleks.

Bali selain dikenal sebagai daerah yang kental akan kesenian dan kebudayaan, namun juga dikenal dengan perbedaan status sosial dalam pembagian kasta yang melingkupi kehidupan masyarakatnya. Situasi dan kondisi masyarakat terutama kaum perempuan sangat tebentur dengan hal tersebut, kebahagiaan, kedamaian, maupun kesengsaraan akibat ketidakadilan tergantung pada status sosialnya. Hal itu terlihat dalam Tarian Bumi mempersoalkan tentang pertentangan nilai dalam masyarakat sehingga muncul tokoh-tokoh yang mewakili 
situasi dan kondisi tersebut, berjuang untuk mendapatkan kebahagiaan dengan menghadapi realitas sosial budaya secara yang tidak sewajarnya dalam adatistiadat Bali.

\section{Metode Penelitian}

Metode penelitian deskriptif merupakan metode dengan menggunakan penggambaran terhadap objek yang diteliti. Menurut Erna dan Mukhtar dalam Konstruksi Ke Arah Penelitian Deskriptif menyatakan bahwa metode deskriptif adalah suatu metode yang digunakan untuk membuat gambaran mengenai situasi atau kejadian (2000: 87). Berdasarkan tujuan penulisan, penelitian ini menggunakan metode deskriptif yaitu penggambaran suatu kejadian atau situasi dalam novel Tarian Bumi.

Tarian Bumi merupakan novel yang menggambarkan masalah sosial, seperti perbedaan kasta yang dialami oleh tokoh-tokohnya. Perbedaan kasta itulah yang menjadi masalah utama untuk dianalisis oleh penulis karena kasta merupakan bagian dari sosial-budaya yang terikat oleh sebuah masyarakat tertentu. Kasta bagi masyarakat Bali adalah lapisan sosial yang sudah ditentukan oleh leluhur mereka terutama bagi penganut Hindu. Namun, dalam novel terdapat beberapa tokoh yang menentang ketentuan adat dan budaya tersebut untuk memperoleh keadilan dan kebahagiaannya.

\section{Pembahasan}

(1) Deskriptif Analisis Latar

Tempat kejadian pada suatu cerita disebut latar. Latar merupakan bagian yang terpenting dalam membangun sebuah karya sastra (Novel) karena dapat memberi penjelasan keadaan suatu peristiwa yang terjadi dalam sebuah cerita, seperti keadaan lingkungan sosial tertentu. Menurut Nurgiyantoro mengutip Abrams (1981: 175) mengungkapkan bahwa latar atau setting adalah menyaran pada pengertian tempat, hubungan waktu, dan lingkungan sosial tempat terjadinya peristiwa-peristiwa yang diceritakan (2007: 216). Berdasarkan konteks tersebut 
maka dapat penulis simpulkan bahwa meneliti masalah sosial maupun nilai sosial lainnya dapat dicari dengan cara menganalisis latar dalam novel.

\subsubsection{Latar Tempat}

Bali merupakan latar utama dalam novel Tarian Bumi karena cerita dalam novel menggambarkan tentang sosial-budayanya. Bali sangat terikat dengan ketentuan adat dan budayanya, salah satunya adalah lapisan sosial. Menurut Depdikbud dalam Pakaian Adat Tradisional Bali menyebutkan bahwa dasar terwujudnya pelapisan sosial resmi di antaranya keaslian, senioritas, keturunan, dan kekuasaan (1988: 13). Berdasarkan pelapisan tersebut dapat menunjukkan perbedaan suatu jenis kedudukan terhadap yang lain.

Uraian di atas bila dihubungkan dengan novel, maka penulis mengambil lapisan sosial berdasarkan keturunan yaitu terletak pada kasta, karena kasta merupakan bagian dari gejala sosial sehingga menjadi permasalahan sosial di dalam novel. Depdikbud menambahkan bahwa menurut dasar keturunan dibedakan atas empat yaitu Brahmana, Ksatria, Wesya, dan Sudra (1988: 14). Namun, dalam Tarian Bumi hanya menceritakan dua kasta yaitu kasta Brahmana dan Sudra.

Konon kata orang Luh Sekar memang selalu menampik cinta laki-laki sudra. Dia juga pernah bercerita pada sahabatnya, Luh Kenten, bahwa dia hanya ingin menikah dengan laki-laki brahmana, seorang Ida Bagus (TB, 2004: 26).

\section{a. Pasar Badung dan Pasar Kumbasari}

Dalam Tarian Bumi pengarang tidak menyebutkan secara jelas letak desa tempat peristiwa cerita, namun hanya beberapa tempat yang disebutkan seperti Pasar Badung dan Pasar Kumbasari. Bali merupakan provinsi yang terdiri dari beberapa kabupaten. Menurut Depdikbud dalam Upacara 
Tradisional Daerah Bali menyebutkan bahwa Bali memiliki delapan kabupaten (1984: 6). Badung merupakan satu dari delapan kabupaten tersebut, tetapi letak Pasar Kumbasari tidak disebutkan namun dapat disimpulkan letaknya masih berada dalam kabupaten Badung.

Pasar merupakan tempat berkumpulnya orang berdagang. Begitupun Pasar Badung tempat berdagang masyarakat Bali. Selain berseni, masyarakat Bali juga dikenal sebagai orang yang rajin, ulet, dan terampil. Seperti yang disebutkan oleh Depdikbud dalam Pandangan Generasi Muda Terhadap Upacara Perkawinan Adat di Kota Denpasar bahwa masyarakat Bali pada umumnya rajin, ulet, terampil, dan berjiwa seni (1998: 16). Karena itu dalam persentase menyebutkan bahwa Bali lebih besar di sektor perdagangan.

Uraian di atas tergambar dalam novel yaitu menggambarkan keuletan dan kerajinan tokoh dalam menjalani hidup yaitu dengan berdagang di sisi lain dari berseni.

Luh Dalem, perempuan sederhana yang tidak memiliki kemampuan apa pun. Luh Dalem hanya bisa berkebun dan berternak babi (TB, 2004: 58).

Terseok-seok Luh Sekar menyeret babi yang akan dijual. Dari orang-orang pasar Luh Sekar baru tahu mengenai malapetaka yang menimpa ibunya (TB, 2004: 60).

Sedikit gambaran yang diceritakan dalam novel mengenai latar Pasar Badung dan Pasar Kumbasari, karena latar tersebut merupakan gambaran masa kecil tokoh utama Luh Sekar bersama ibunya Luh Dalem. Meskipun demikian, gambaran tersebut merupakan bagian yang menjadi timbulnya masalah sosial dalam cerita novel.

Dalam Tarian Bumi, Pasar Badung dan Pasar Kumbasari adalah tempat berjualan ternak Luh Dalem ibu dari Luh Sekar. Karena kondisi keluarga yang tidak berkecukupan, Luh Dalem rela menjual hasil ternaknya demi dapat menyekolahkan anaknya Luh Sekar. Di samping kemiskinan, 
keluarganya pun dikucilkan masyarakat desanya karena ayah Sekar dianggap orang yang terlibat dalam gerakan PKI.

“Kata mereka, aku anak pengkhianat. Anak PKI! Yang berbuat ayahku, yang menanggung beban aku dan keluargaku." (TB, 2004: 27).

"Kalau saja ayahnya tidak terlibat gerakan tidak jelas itu, orang-orang desa tentu tidak akan menghukum keluarga Luh sekar seperti ini. Dan ibunya, Luh Dalem, tidak akan sampai buta" (TB, 2004: 58).

Kebutaan Luh Dalem terjadi di pasar Kumbasari ketika ia akan menjual ternaknya yang seharusnya ditemani oleh Sekar.

Sekar tidak bisa ikut ibunya menjual babi ke pasar Kumbasari (TB, 2004: 58).

Tidak ada baju, tidak ada sepatu, kue, atau permen. Tidak juga uang, Luh Sekar melihat ibunya dipobong orang-orang sedesa. Tubuh perempuan itu berlumuran darah. Luh Sekar menjerit-jerit (TB, 2004: 59).

Sejak itu masyarakat desa peduli terhadap Luh Sekar dengan memberikan sedikit perhatian karena merasa iba melihat keadaan ibunya.

"Sudah makan, Luh?" tanya seorang pedangan buah di pasar Badung (TB, 2004: 60).

“..., yang sering menuntun babinya ke Pasar Badung adalah Wayan Ranten, pedagang ayam potong" (TB, 2004: 62).

\section{b. Griya (Tempat tinggal kasta Brahmana)}


Tempat tinggal bagi adat Bali merupakan atribut yang membedakan lapisan sosial masyarakatnya. Hal ini disebutkan oleh Depdikbud bahwa atribut yang membedakan lapisan asli dan tak asli tampak dalam beberapa hal, antara lain pakaian adat dan rumah tempat tinggal (1988: 13). Namun, dalam Tarian Bumi hanya menceritakan tokoh-tokoh dengan lapisan asli atau warga desa asli Bali karena dalam novel menggambarkan kesehariannya di tempat tinggal atau rumah adat Bali, seperti Griya.

Griya menurut pengarang Oka Rusmini adalah tempat tinggal keluarga Brahmana (2004: 7). Di latar ini terdapat berberapa peristiwa yang menggambarkan hubungan sosial tokoh-tokoh yang tinggal di Griya. Seperti ketidakharmonisan maupun hubungan yang baik antara satu tokoh dengan tokoh lainnya.

Dalam latar Griya ini beberapa cerita menggambarkan ketidakharmonisan hubungan antara mertua dengan menantu yaitu hubungan antara Ida Ayu Sagra Pidada dengan Luh Sekar (Jero Kenanga) dalam hal mendidik Telaga.

Di mata Telaga, dua orang perempuan di rumah ini telah membuatnya jadi serba salah. Kalau Jero Kenanga masuk ke kamar telaga, neneknya pasti akan menatap dengan perasaan tidak senang. (TB, 2004: 91).

"Apa dia memberimu nasihat" suara Ibu lebih mirip penyelidikan. Telaga diam ... (TB, 2004: 85).

Gambaran dari kutipan di atas menunjukkan bahwa hubungan antara nenek dan ibu Telaga tidak harmonis, mereka saling selidik-menyelidiki jika satu dari mereka memberi nasihat pada Telaga. Hal itu terjadi karena latar belakang kehidupan mereka yang menjadi pengaruh dalam perkembangan Telaga yang menurut Sekar, Ida Ayu Sagra Pidada adalah orang yang tidak pernah merasakan susah selama hidupnya dan tidak memiliki banyak pengalaman. 
"Harus hati-hati mendengar nasihat tuniang-mu. Perempuan itu tidak banyak pengalaman. Dia seorang perempuan bangsawan yang hidupnya sejak kanak-kanak sampai hari ini selalu berlimpah" (TB, 2004: 92).

Sekar sepertinya khawatir Telaga tidak akan bisa mandiri bila harus mengikuti arus jalan hidup seperti neneknya. Ia ingin mengajarkan pada anaknya tentang kesulitan hidup seperti yang dialami ibunya dahulu, segala sesuatu perlu perjuangan begitupun demi kebahagiaan. Sebaliknya, neneknya khawatir bila Telaga harus menerima nasihat ibunya yang dulunya hanya seorang penari joged.

"Aku bicara yang sesungguhnya. Bagaimana mungkin seorang penari joged yang tubuhnya biasa disentuh laki-laki bisa menasihati cucuku dengan baik.” (TB, 2004: 92).

Meskipun kedua tokoh tersebut saling bertentangan, namun mereka memiliki satu tujuan yang sama yaitu sama-sama ingin membentuk kepribadian Telaga dengan baik. Selain itu, mereka hanya merasa saling tersaingi untuk mendapatkan rasa sayang dari Telaga.

Di samping ketidakharmonisan dari hubungan antara kedua tokoh di atas, latar Griya juga menggambarkan hubungan yang baik antara Sekar dengan Telaga sebagai hubungan ibu dan anak meskipun sedikit adanya rasa berontak dari jiwa Telaga karena ambisi Sekar. Keharmonisan dirasakan Telaga karena kelembutan dan kasih sayang Sekar pada Telaga. Namun, di sisi lain Telaga tidak suka dengan ambisi ibunya yang mungkin menurut adat dan budaya Bali benar, tetapi bagi Telaga hal tersebut merupakan tekanan karena tidak sesuai dengan pemikiran dan keinginan hatinya.

Sekar ingin Telaga menikah dengan seorang Ida Bagus. Permohonan itu ia nyatakan ketika ia menemui Telaga di kamarnya. Saat itu, Telaga sudah memasuki masa dewasa dan telah menjalani upacara Menek Kelih yang 
menurut pengarang dalam novelnya berarti sebuah upacara pembabtisan lahirnya seorang gadis baru (2004: 80).

"Kau adalah harapan Meme, Tugeg. Kelak, kau harus menikah dengan laki-laki yang memakai nama depan Ida Bagus..." (TB, 2004: 84).

Menjadi penari pun merupakan bagian dari ambisi Sekar terhadap Telaga. Namun, dalam hal ini Telaga tidak menolaknya karena menjadi penari adalah hal yang biasa bagi perempuan Bali. Selain itu, karena menjadi penari ia dapat bertemu dan jatuh cinta pada Wayan Sasmita.

Rumah Ida Bagus Ketu Pidada merupakan bagian dari latar tempat griya, karena di sana terdapat peristiwa-peristiwa penting mengenai hubungan sosial antara tokoh utama Telaga dengan Wayan Sasmita.

Telaga tumbuh bersama Wayan Sasmita. Wayan sering datang ke griya untuk menemui Ida Bagus Ketu Pidada. Telaga memanggil laki-laki tua itu "kakek". (TB, 2004: 141).

Latar ini merupakan tempat Wayan belajar melukis dan menari, sejak kecil ia diajarkan oleh kakek Ketu sehingga kepribadiannya terlihat berbeda dengan lelaki Sudra lainnya. Latar ini menggambarkan awal mulanya perasaan Telaga tumbuh terhadap Wayan Sasmita. Mereka sering dijadikan objek lukisan kakek Ketu dan tampil sebagai sepasang penari oleg, karena hal itu mereka diam-diam saling memiliki ketertarikan.

\section{c. Rumah Luh Dalem atau Luh sekar}

Dalam latar ini terdapat beberapa gambaran hubungan sosial yang berkaitan dengan keluarga Luh Dalem. Latar ini dalam novel tidak disebutkan letak daerahnya hanya disebutkan sebagai desa. Namun, dapat disimpulkan bahwa latar rumah ini masih bagian dari kabupaten Badung, Bali. 
Suatu hari karena harus ikut ujian di sekolah, Sekar tidak bisa ikut ibunya menjual babi ke Pasar Kumbasari.

(TB, 2004: 58).

Dalam latar ini, peristiwa tidak banyak digambarkan dalam novel namun memiliki beberapa nilai sosial yang dapat diketahui. Seperti hubungan sosial antara Luh Sekar dengan Ibunya, Luh Dalem, hubungan Luh Sekar terhadap adiknya Luh Kerti dan Luh Kerta.

Latar rumah yang disebutkan oleh pengarang dalam novel salah satunya adalah rumah Luh Dalem, tempat tinggal tokoh utama Luh Sekar saat ia masih kecil sampai dewasa atau sebelum menikah dengan Ida Bagus Ngurah Pidada dan tinggal di Griya. Hubungan Luh Sekar dengan Ibunya, Luh Dalem sangat baik. Sekar sangat menyayangi dan mencintai ibunya karena ia merasakan betapa besar perjuangannya untuk bisa menghidupi anaknya tanpa seorang suami di sampingnya. Terlebih saat ibunya mengalami kebutaan, ia merasakan kesedihan yang dalam.

Di usia sangat kecil, Luh Sekar bisa merasakan begitu banyak penderitaan yang bergantung pada pundak perempuan yang teramat dicintainya itu. (TB, 2004: 59).

Sebaliknya, hubungan Luh Sekar dengan adik kembarnya Luh Kerta dan Luh Kerti tidak sebaik dengan hubungan Luh Sekar dengan ibunya. Sejak kecil Sekar peduli terhadap adik-adiknya, hal itu tergambar dalam novel bahwa Sekar tidak menerima ketika ibunya ingin menggugurkan kandungan yang tidak jelas ayahnya.

Luh Sekar tidak menerima itu. Bagi Sekar, alangkah jahat ibunya tega membunuh calon adiknya. (TB, 2004: 64).

Sebelumnya, Luh Kerta dan Luh Kerti adalah anak yang tidak diinginkan oleh ibunya karena mereka dihasilkan dari malapetaka yang menimpa Luh Dalem. Selain mengalami kebutaan, Luh Dalem juga diperkosa 
oleh laki-laki yang tidak bertanggung jawab. Hal itu diketahui oleh Sekar saat ia menjual ternaknya di Pasar Badung.

Kata orang-orang itu ibu Sekar diperkosa oleh lebih dari tiga

laki-laki. Luh Sekar bergidik mendengar cerita itu.

(TB, 2004: 60).

Setelah dewasa pun Sekar selalu sabar menghadapi tingkah laku adikadiknya yang setelah selalu menyusahkannya dan ibunya. Terlebih diketahui mereka bahwa kelahiran mereka tidak diinginkan.

Capek sekali Sekar harus menyantuni kedua adiknya yang

tidak pernah puas dan maunya menang sendiri saja itu.

(TB, 2004: 66).

Kejahatan dan kesinisan dari kedua adiknya tergambar jelas ketika Luh Sekar sudah menjadi istri seorang Ida Bagus saat Sekar mendatangi rumahnya untuk menemui ibu dan adik-adiknya. Kedua adiknya bersikap menyindir dan berkata yang tidak sopan padanya.

"Jero sekarang terlihat sangat cantik. Pasti suami Jero betah

di rumah, dan tidak akan terpikat perempuan-perempuan lain..” (TB, 2004: 70).

Kesakitan yang harus diterima Sekar saat mengetahui bahwa ternyata kedua adiknya mau dijadikan peliharaan suaminya. Namun, ia tetap bersabar dan menerimanya karena ia tahu bahwa untuk menjadi istri seorang bangsawan ia harus membayar mahal.

\section{d. Rumah Luh Kenten}

Latar ini merupakan bagian latar yang memiliki gambaran penting dalam cerita karena menggambarkan perjuangan tokoh Sekar utnuk menjadi seorang penari. Meskipun tidak secara jelas gambaran latarnya namun terlihat saat Sekar menemui sahabatnya Luh Kenten di biliknya. 
Suatu hari Sekar datang malam-malam ke biliknya. Wajah perempuan itu terlihat lembab. Dia menubruk Kenten, dan memeluk tubuh perempuan yang berbeda lima tahun itu eraterat. (TB, 2004: 45).

Berdasarkan kutipan di atas maka dapat penulis simpulkan bahwa rumah Luh Kenten merupakan tempat yang biasa Sekar memberi cerita tentang keinginan dan ambisinya kuatnya untuk menjadi seorang penari joged dan istri seorang Ida Bagus pada sahabatnya Luh Kenten.

“Aku capek miskin, Kenten. Kau harus tahu itu. Tolonglah, carikan aku seorang Ida Bagus. Apa pun syarat yang harus kubayar, aku siap!” (TB, 2004: 27).

Hubungan sosial antara Luh Sekar dengan Luh Kenten sangat baik karena mereka adalah sahabat baik yang memiliki kesamaan, yaitu tidak pernah mendapatkan kasih sayang dari seorang Ayah.

"Aku adalah perempuan yang tak pernah mengenal wajah laki-laki yang ikut membentuk tubuhnya." (TB, 2004: 34).

Kesamaan itulah yang membuat mereka merasa senasib tergolong kasta sudra yang miskin dan seperjuangan untuk mendapatkan kebahagiaan mereka. Namun, yang membedakan mereka adalah Luh Sekar berkeinginan untuk menikah dengan seorang Ida Bagus untuk mengubah nasibnya, sedangkan Luh Kenten tidak ada keinginan untuk menikah karena menurutnya perempuan bisa hidup tanpa laki-laki.

"Ya, Meme. Ini aku ucapkan dengan kesungguhan, kita bisa hidup tanpa laki-laki. Aku akan buktikan ucapan ini."

(TB, 2004: 42).

Dalam novel terdapat menggambarkan hubungan baik antara Luh Sekar dan Luh Kenten. Setiap kali Sekar ingin bercerita Kenten selalu setia mendengar keluhannya, meskipun dengan jawaban yang tidak menyenangkan 
namun ia sangat berharap kalau Sekar menemukan kebahagiaannya. Hal itu tergambar saat Telaga memintanya untuk menemani ke Pura untuk berdoa dan meminta pada para Dewa agar menjadikannya seorang penari.

"Untuk apa kau ke pura malam-malam."

"Aku ingin sembahyang, Kenten. Bicara pad para dewa agar

mereka tahu aku sungguh-sunguh ingin menjadi seorang penari joged."

"Apa yang kaulakukan kalau para dewa tidak mengabulkan

dоати?"

“Kau jangan bicara seperti itu.” (TB, 2004: 48).

Setelah terkabul menjadi penari, Luh Kenten pun tetap mendukungnya sampai Luh Sekar menikah dengan Ida Bagus Ngurah Pidada.

\section{e. Rumah Wayan Sasmita atau Luh Gumbreg}

Latar ini digambarkan dalam novel oleh pengarang tanah seluas 20 are atau sama dengan $2000 \mathrm{~m}^{2}$. Namun, pengarang tidak menggambarkan luas tanah yang dibangun untuk rumah Wayan tersebut. Sebagai masyarakat berkasta Sudra, rumah ini tidak sebagus dan seluas rumah-rumah yang berada di Griya atau tempat tinggal para kasta Brahmana.

Dalam latar ini terdapat beberapa peristiwa yang berhubungan dengan keadaan sosial antartokohnya yaitu keadaan yang tergambar jelas perbedaan status sosialnya. Karena perbedaan tersebut maka muncullah pertentangan yang berkaitan denga adat dan budaya Bali.

Perasaan Telaga dan Wayan sudah tidak dapat lagi dibendung, maka mereka pun secara tidak wajar menentang adat dan istiadat Bali yaitu ingin meresmikan hubungannya dengan status sosial yang berbeda. Mereka menemui ibu Wayan di rumahnya, tetapi Luh Gumbreg secara tegas menolak keinginan dari kedua tokoh tersebut, karena baginya menikah dengan perbedaan status merupakan aib bagi keluarganya. 
"Meme perempuan kolot, Tugeg. Perempuan kampung.

Meme tetap tidak bisa menerima hubungan ini. Aib."

(TB, 2004: 175).

Pertentangan pun dilalui karena kehamilan yang dialami oleh Telaga yang akhirnya mereka direstui untuk menikah. Setelah tinggal di rumah Wayan, Telaga merasakan sebuah perubahan besar, ia harus menjadi perempuan Sudra yang segala sesuatunya harus dikerjakan sendiri, tidak ada pembantu atau siapapun yang membantunya seperti saat ia masih tinggal di Griya.

Perubahan yang dialami Telaga juga adalah sikap Luh Gumbreg, ia masih kecewa atas pilihan anaknya yang menikah dengan seorang Dayu, seorang perempuan Brahmana. Ia bersikap yang tidak biasanya seperti waktu Telaga masih menjadi tuannya di Griya. Begitu pun sikap adik Wayan, Luh Sadri, ia tak sebaik sewaktu menjadi sahabatnya. Ia kecewa dengan Telaga karena tidak sesuai harapannya yang menurutnya Telaga akan membawa barang-barang dari Griya seperti perangkat pakaian dan perhiasan.

"Enak sekali perempuan itu. Ketika menikah satu lembar pakaian pun tidak dia bawa ..." (TB, 2004: 200).

Latar tempat ini, dalam rumah Wayan ini hanya ia yang bersikap baik pada Telaga, ia bertanggung jawab mengurusi istrinya dengan bekerja keras mengadakan pameran lukisannya. Sesuai janjinya ia akan membahagiakan Telaga dan akan mewujudkan impian mereka.

Sudah hampir satu bulan Wayan belum pulang juga dari

Jakarta. Dia pameran. (TB, 2004: 190).

Namun, kebahagiaan itu tidak lama Telaga rasakan karena Wayan meninggalkannya terlebih dahulu. Luh Gumbreg pun sangat kecewa saat diketahui anak sulungnya meninggal di studio lukis rumahnya. Ia masih 
beranggapan bahwa meninggalnya Wayan atas kesialan karena telah menikah dengan perempuan Ida Ayu.

"Berkali-kali tiang berkata, menikah dengan perempuan Ida Ayu pasti mendatangkan kesialan.” (TB, 2004: 193).

Namun, sikap Luh Gumbreg sedikit berubah lebih baik terhadap Telaga setelah Luh Sadri menikah dan tidak tinggal serumah. Kehadiran Luh Sadri hanyalah membuat keadaan rumah Luh Gumbreg menjadi panas karena emosi, tidak ada kedamaian karena ia selalu mempengaruhi ibunya tentang Telaga.

"Meme mulai kena guna-gunanya. Meme mulai mencintai dia. Awas, hari-hati. Perempuan-perempuan bangsawan selalu memiliki ilmu leak untuk menguasai apa saja yang jadi keinginannya." (TB, 2004: 203).

Sikap Luh Gumbreg tergambar dalam novel, ketika Luh Sasdri meminta Ibunya untuk memberi sebagian tanahnya. Ia mengeluh karena hidupnya susah karena suaminya tidak bekerja, ia ingin pindah dan tinggal lagi di rumah ibunya.

"Itu pilihanmu. Kau harus menanggung risiko dari pilihanmu. Telaga juga berani kawin dengan Wayan. Dan sampai saat ini dia tetap bertahan." (TB, 2004: 203).

\section{(2) Latar Waktu}

Latar waktu merupakan latar yang menggambarkan waktu sebuah peristiwa dalam cerita. Menurut Nurgiyantoro latar waktu berhubungan dengan masalah "kapan" terjadinya peristiwa-peristiwa yang diceritakan dalam sebuah karya fiksi (2007: 230). Namun, dijelaskan kembali oleh Nurgiyantoro bahwa masalah "kapan" dikaitkan dengan peristiwa sejarah. Berdasarkan konteks tersebut penulis simpulkan bahwa analisis latar waktu 
tidak hanya dalam teks namun dapat dilihat dari luar teks seperti sejarah yang menjadikan karya sastra tertentu.

Dalam Tarian Bumi terdapat cerita yang berkaitan dengan sejarah, namun pengarang tidak menjadikannya sebagai latar belakang dalam novelnya sehingga cerita dalam novel secara utuh menggambarkan sosialbudaya daerah Bali yang sampai saat ini masih dianut oleh masyarakatnya.

“Kata mereka, aku anak pengkhianat. Anak PKI! Yang berbuat ayahku, yang menanggung beban aku dan keluargaku..."

(TB, 2004: 27).

Nurgiyantoro mengutip Genette (1980: 33; 35) menyebutkan bahwa masalah waktu dalam karya naratif bermakana ganda yaitu satu pihak menyaran pada waktu penceritaan, waktu penulisan cerita, dan di pihak lain menunjuk pada waktu dan urutan waktu yang terjadi dan dikisahkan dalam cerita (2007: 231).

Berdasarkan konteks dan hal-hal di atas maka penulis tidak menggunakan gambaran di luar teks untuk menganalisis latar waktu tetapi menggunakan latar waktu yang berhubungan dengan peristiwa-peristiwa yang diceritakan dalam novel.

Dalam Tarian Bumi terdapat gambaran yang menunjukkan waktu suatu peristiwa, tetapi gambaran cerita tidak menunjukkan waktu secara jelas karena hanya menekankan waktu seperti sore dan malam.

Telaga mulai menari. Terus menari, sampai tak terasa lagi sebuah senja milikinya telah hilang, menguap dan digantikan malam. (TB, 2004: 99).

Gambaran kutipan di atas pada saat Telaga mulai belajar menari dengan Luh Kambren. Ia hanya diberi waktu sore di setiap harinya oleh Jero Kenanga untuk belajar menari. Tidak lama bagi Telaga untuk bisa menari karena secara perlahan Luh Kembren menyukainya dan memberikan seluruh taksunya kepada Telaga. 
"Ambil semua taksu yang tiang punya. Tugeg memang pilihan!" (TB, 2004: 4).

Selain waktu sore, Tarian Bumi menggunakan beberapa gambaran waktu malam dalam peristiwa latar waktunya. Satu diantaranya yaitu saat Luh Sekar berjuang mewujudkan ambisinya menjadi seorang penari.

“Kau berani malam-malam begini ke pura?” (TB, 2004: 49).

Gambaran dari kutipan di atas merupakan potongan dialog antara Sekar dengan Luh Kenten. Luh Sekar mendatangi bilik atau rumah Luh Kenten untuk memintanya menemani Sekar bersembahyang ke Pura sekaligus berdoa dan memohon pada para Dewa agar merestuinya untuk menjadi seorang penari.

Berdasarkan kedua kutipan waktu di atas dapat penulis simpulkan bahwa pengarang lebih dominan menggunakan latar waktu sore dan malam dalam novelnya karena dari kedua latar waktu tersebut memiliki makna yang menunjukkan gambaran kisah hidup tokoh utama dalam cerita.

Senja yang selalu membuat Telaga merasa sedih, karena saat menatap langit dia rasakan potret hidupnya bergantung di sana.

Setiap melatih tari, diam-diam Kambren mencuri Telaga agar tidak sering-sering duduk di pintu dan menyaksikan malam melahap senja miliknya. (TB, 2004: 100).

Selain waktu sore dan malam, terdapat gambaran waktu yang menunjukkan tanggal yaitu gambaran ketika Telaga melahirkan seorang anak perempuannya.

30 September. Telaga mendapatkan sebuah permainan baru.

Dia lahir. Seorang perempuan. Matanya benar-benar melambangkan mata perempuan Bali bulat dan sangat tajam. (TB, 2004: 191). 


\section{(3) Latar Sosial}

Latar sosial merupakan latar yang berhubungan dengan kehidupan sosial dalam karya fiksi. Nurgiyantoro menyebutkan bahwa latar sosial menyaran pada hal-hal yang berhubungan dengan perilaku kehidupan sosial masyarakat di suatu tempat yang diceritakan dalam karya fiksi (2007: 233). Berdasarkan konteks tersebut penulis menyimpulkan bahwa latar sosial menggambarkan kehidupan sosial yang berhubungan dengan perilaku masyarakat.

Dalam kehidupan sosial melahirkan beberapa pandangan atau cara berpikir yang berbeda-beda sehingga menimbulkan berbagai permasalahan sosial. Nurgiyantoro menambahkan bahwa masalah dalam ruang lingkup masyarakat dapat berupa kebiasaan hidup, adat istiadat, tradisi, keyakinan, pandangan hidup, cara berpikir dan bersikap, dan lain-lain (2007: 233).

Berdasarkan konteks dia atas penulis mengambil beberapa hal yang dikemukakan sebagai analisis latar sosial karena Tarian Bumi menyajikan beberapa permasalahan sosial seperti adat istiadat dan tradisi yang tergambar dalam novel.

\section{(4) Latar Suasana}

Dalam Tarian Bumi terdapat gambaran yang menunjukkan kondisi jiwa tokoh sehingga mampu menciptakan suasana cerita, seperti suasana senang, sedih, mengharukan, dan menegangkan. Hal itu penulis gambarkan dalam analisis latar suasana.

\section{a. Suasana Menyenangkan}

Gambaran suasana menyenangkan dalam Tarian Bumi tidak banyak ditunjukkan oleh tokoh dalam cerita. Namun, suasana tersebut dapat digambarkan oleh tokoh utama cerita yaitu Ida Ayu Telaga Pidada. Kesenangan yang ia rasakan adalah saat keinginannya terwujud yaitu menikah dengan lelaki yang ia cintai, Wayan Sasmita. 
"Lihat, Telaga, dia begitu luar biasa. Kakinya selalu menendangi wajah tiang” teriak Wayan. "Kelihatannya dia membenci tiang”

"Kau ada-ada saja."

"Sungguh. Lihat! Setiap tiang mencium pipinya dia menangis keras-keras."

Telaga tersenyum. Diusapnya rambut Wayan penuh kasih. (TB, 2004:92).

Kutipan di atas merupakan gambaran suasana yang menyenangkan bagi Telaga karena telah melahirkan seorang perempuan hasil buah cintanya dengan Wayan yang mereka beri nama Luh Sari.

\section{b. Suasana Menyedihkan}

Gambaran suasana menyedihkan dialami oleh tokoh Telaga yaitu saat ia harus kehilangan lelaki yang sangat ia cintai. Sejak itu, suasana yang digambarkan dalam novel hanya gambaran kesedihan. Salah satu suasana tersebut tergambar dalam kutipan sebagai berikut:

Telaga terdiam. Dia juga telah lelah menangis. Dia tidak menyangka hidup begitu cepat merenggut laki-laki dalam hidupnya. Laki-laki yang memberinya jalan untuk memahami arti menjadi perempuan. (TB, 2004: 94).

Peristiwa itu tergambar saat Telaga harus menerima resikonya yang telah menikah dengan lelaki Sudra. Salah satu hukum adat yang ia terima adalah kehilangan suaminya, yaitu Wayan Sasmita.

\section{c. Suasana Mengharukan}

Gambaran suasana mengharukan ini ditunjukkan oleh Telaga saat ia berguru tari dengan Luh Kambren. Ia mengagumi gurunya karena kepribadian dan komitmennya sebagai penari. 
"Hidupku hanya untuk menari" itulah kata-kata Kambren.

Kata-kata yang selalu diingat Telaga. (TB, 2004: 119).

Dalam Tarian Bumi diceritakan bahwa Luh Kambren adalah guru tari yang tidak sembarangan memilih murid. Karena baginya orang-orang belajar tari hanyalah sekedar belajar. Setelah ia mengenal Telaga, ia lansung menyukainya karena melihat bakat yang dimiliki oleh Telaga. Hal itu membuat telaga terharu terhadap gurunya.

"Sudah tiang katakan, Tugeg adalah murid terbaik yang pernah tiang miliki. Tugeg tahu, tiang sudah puluhan tahun tidak ingin mengajari seseorang menari. Melelahkan. Karena mereka sering tidak serius. Tugeg menguasai tari Legong dalam waktu dua hari. Luar biasa!' Luh Kambren memekik. Ditatapnya perempuan di depannya dengan rasa haru yang begitu dalam. (TB, 2004: 4).

\section{d. Suasana Menegangkan}

Gambaran suasana menegangkan ditunjukkan oleh tokoh Luh Kenten, yaitu sahabat dari tokoh Luh sekar atau Jero Kenanga. Ketegangan terjadi saat keinginannya yang menentang dari kodratnya sebagai perempuan. Ia melihat realita yang ada dalam hidupnya, ia memandang bahwa hidupnya tidak adil. Hal itu digambaran dalam novel saat ia berdialog dengan ibunya.

"Aku tidak akan kawin, Meme. Aku tidak ingin mereka bohongi. Aku benci seluruh laki-laki yang membicarakan perempuan dengan cara tidak terhormat!"

"Apa maksudmu? Kau tidak boleh memaki seperti itu. Kau harus menghargai mereka!”

"Mereka tidak pernah menghargai perempuan, Meme."

(TB, 2004: 4). 
Gambaran kutipan di atas menunjukkan gambaran suasana yang menegangkan, yaitu tergambar emosi Luh Kenten saat mengetahui bahwa perempuan begitu rendah di mata lelaki Bali sehingga membuat dirinya berkomitmen untuk tidak menikah.

\section{(5) Latar Budaya}

Semua tokoh yang ada dalam Tarian Bumi memiliki latar budaya Bali yang menjadi dasar pandangan mereka. Meskipun demikian, kehidupan yang mereka jalani sangat berbeda. Hal ini terjadi karena masing-masing tokoh memiliki status sosial yang berbeda yang secara sadar membentuk pandangan budaya dan nilai-nilai sosial mereka.

Secara umum, mereka memiliki karakter yang baik karena mengenal kesopanan, saling menghargai, dan tahu menempatkan diri. Namun, lingkungan membentuk karakter berbeda di setiap tokoh. Luh Sekar yang hidup di lingkungan Sudra yang miskin membutuhkan sikap yang tahan banting dan keras untuk mendapatkan kebahagiaannya agar hidupnya lebih baik. Telaga yang berasal dari keluarga Brahmana yang tidak menganggap bahwa aturan budaya Bali akan membuatnya bahagia sehingga ia mencari kebahagiaannya dengan menikah dengan lelaki Sudra.Ida Ayu Sagra Pidada sebagai penerus dan pewaris keluarga Griya ia memegang teguh nilai-nilai budaya. Oleh karena itulah penulis mendapati beberapa singgungan budaya di antara tokoh-tokoh novel, terutama kebahagian yang mereka dapatkan dalam masyarakat yang berbudaya.

\section{Simpulan}

Gejala sosial yang digambarkan dalam novel adalah adanya segala aturan adat dan istiadat dalam budaya Bali yang mengatur dan harus diikuti oleh masyarakatnya. Seperti adanya pembagian kasta sebagai pertanda atas perbedaan kelas sosialnya sehingga kebahagiaan yang dirasakan oleh masyarakatnya tidak merata atau tidak menyeluruh. Hal tersebut membuat tekanan dan penderitaan 
yang dialami oleh masyarakatnya. Oleh karena keadaan tersebut mendorong tokoh Luh Sekar dan Ida Ayu Telaga untuk melakukan hal yang menurut budaya Bali adalah penyimpangan atau larangan demi mendapatkan kebahagiaannya.

Adanya gejala sosial menimbulkan hubungan sosial yang menciptakan kebersamaan dan pertentangan. Kebersamaan dalam arti adalah keharminosan hubungan antartokoh, sedangkan pertentangan diartikan sebagai hubungan sosial yang menimbulkan masalah atau konflik. Dalam Tarian Bumi lebih mengarah pada hubungan sosial yang mengandung pertentangan akibat dari gejala sosial yang dialami oleh tokoh-tokohnya. Luh Sekar seorang perempuan Sudra berani menikah dengan seorang Ida Bagus, ia harus menerima sikap keras mertuanya, Ida Ayu Sagra Pidada seorang perempuan Brahmana yang pemegang teguh akan nilai-nilai budaya sehingga ia tidak menyukai atas pernikahan anaknya yang berbeda kasta. Selain itu, tergambar juga sikap Luh Sadri yang iri dan tidak bersahabat terhadap Ida Ayu Telaga, karena merasa dirinya tidak secantik dan sekaya Telaga yang adalah seorang perempuan bangsawan.

Tarian Bumi berlatarkan daerah Bali, di mana dalam cerita tergambar latar-latar yang terdapat nilai-nilai sosialnya. Seperti latar Pasar merupakan tempat berkumpulnya masyarakat untuk melakukan interaksi antara penjual dan pembeli, latar Griya (tempat tinggal kaum Brahmana) dan tempat tinggal kaum Sudra merupakan tempat tinggal yang berbeda berdasarkan status sosialnya begitu juga berbeda dalam bersikap dan berperilaku penduduknya.

\section{Daftar Pustaka}

Damono, Sapardi Djoko. 1978. Sosiologi Sastra: Sebuah Pengantar Ringkas. Jakarta: Depdikbud.

Departemen Pendidkan dan Budaya. 1988. Pakaian Adat Tradisional Daerah Bali. Jakarta: Depdikbud. . 1984. Upacara Tradisional Daerah Bali. Jakarta: Depdikbud.

- 1998. Pandangan Generasi Muda Terhadap Upacara Perkawinan Adat di Kota Denpasar. Jakarta: Depdikbud. 
Eck, R. Van. 1978. Peran dan Kedudukan Wanita Indonesia. Yogyakarta: Gajah Mada University Press.

Eddy, Nyoman Tusthi. 1991. Mengenal Sastra Bali Modern. Jakarta: Balai Pustaka.

Escarpit, Robert. 2008. Sosiologi Sastra. Jakarta: Yayasan Obor Indonesia.

Noor, Redyanto. 2005. Pengantar Pengkajian Sastra. Semarang: Fasindo.

Nurgiyanto, Burhan. 2007. Teori Pengkajian Fiksi. Yogyakarta: Gajah Mada University Press.

Panuju, Redi. 1994. Ilmu Budaya Dasar dan Kebudayaan. Jakarta: PT. Gramedia Pustaka Utama.

Pradopo, Rachmat Djoko. 2005. Beberapa Teori Sastra, Metode Kritik, Dan Penerapannya. Yogyakarta: Pustaka Pelajar.

1994. Prinsip-prinsip Kritik Sastra: Teori dan Penerapannya. Yogyakarta: Gajah Mada University Press.

Pradopo, Rachmat Djoko, dkk. 2002. Metode Penelitian Sastra. Yogyakarta: PT. Hanindita Graha Widya.

Ratna, Nyoman Khuta. 2009. Teori, Metode, dan Teknik Penelitian Sastra. Yogyakarta: Pustaka Pelajar.

Rusmini, Oka. 2004. Tarian Bumi: Sebuah Novel. Magelang: Indonesiatera. 12 Juli 2013.

"Penulis Oka Rusmini". www.tamanismailmarzuki.com. Jumat,

Sastrowardoyo, Subagio. 1999. Sekilas Soal Sastra dan Budaya. Jakarta: Balai Pustaka.

Stanton, Robert. 2007. Teori Fiksi. Yogyakarta: Pustaka Pelajar.

Sunarta, Wayan. "Oka Rusmini, Pendobrak Tabu dari Bali". www.journalbali.com. Rabu, 10 Oktober 2012.

Teeuw, A. 1984. Sastra dan Ilmu Sastra: Pengantar Teori Sastra. Jakarta: Pustaka Jaya.

Wellek, Rene \& Austin Werren. 1989. Teori Kesusastraan. Jakarta: PT Gramedia. 